\title{
Goldfish (Carassius auratus) Image Segmentation Using Expectation Maximization (EM) Algorithm
}

\author{
Yunda Heningtyas ${ }^{1 *}$, Rico Andrian ${ }^{2 *}$, Akmal Junaidi ${ }^{3 *}$, Susiyani ${ }^{4 *}$ \\ * Ilmu Komputer, Fakultas Matematika dan Ilmu Pengetahuan Alam, Universitas Lampung \\ yunda.heningtyas@fmipa.unila.ac.id ${ }^{1}$, rico.andrian@fmipa.unila.ac.id ${ }^{2}, \underline{\text { susiyani226@gmail.com }}^{4}$
}

\begin{tabular}{l} 
Article Info \\
\hline Article history: \\
Received 2020-08-24 \\
Revised 2020-09-14 \\
Accepted 2020-09-17
\end{tabular}

Keyword:

Goldfish Identification, Goldfish Segmentation, Expectation Maximization, Ornamental Fish.

\begin{abstract}
Carassius Auratus, also known as goldfish, is the most commonly kept ornamental fish in an aquarium that has a variety of species, shapes, and colors. Goldfish anatomy is almost similar between species so it is difficult to distinguish. Goldfish identification has several processes to determine the level of success. One process that is very important for identification is segmentation. Segmentation is the stage to separate objects and backgrounds. Good segmentation results will provide maximum feature extraction results and it should impact on optimal identification results. This research aims to create a system that can be used to segment goldfish fish objects in the background using the Expectation-Maximization method. Expectation-Maximization is an algorithm for estimating a parameter in a function by using Maximum Likelihood Estimation (MLE). Goldfish fish species total of 72 images each totaling 216. Goldfish segmentation evaluation results using the Expectation-Maximization method can work well with an accuracy rate of $89.14 \%$. Analysis of the results of the imperfect fish image segmentation is influenced by white light and the background color is almost similar to that of the goldfish. The results of the best goldfish image segmentation are influenced by a good goldfish image when the image capture process at the time of the screenshot has a stable focus and is not blurry so that the edges of the goldfish object appear clearly and sharply.
\end{abstract}

This is an open access article under the $\mathrm{CC}-\mathrm{BY}-\mathrm{SA}$ license.

\section{Pendahuluan}

Perairan di Indonesia yang sangat luas menjadikan Indonesia memiliki berbagai spesies ikan hias yang sangat beragam. Pulau Jawa, Sumatera, Kalimantan, dan Irian Jaya memiliki spesies ikan hias masing-masing. Ketersediaan sumber daya ikan hias yang berlimpah menjadikan ikan hias sebagai salah satu komoditas perdagangan dengan potensi tinggi baik domestik maupun ekspor [1]. Salah satu ikan hias yang memiliki jumlah peminat tinggi sepanjang tahun adalah ikan Maskoki [2].

Distribusi ikan hias didominasi oleh Kabupaten Tulung Agung, Jawa Timur [3]. Ikan Maskoki merupakan jenis ikan hias air tawar yang paling banyak dipelihara oleh masyarakat [4]. Spesies ikan Maskoki pun beragam, diantaranya Oranda, Ranchu, Fantail. Cara membedakan Ikan Maskoki berdasarkan warna, ukuran dan corak tubuh. Ikan Maskoki mempunyai sirip ekor yang bervariasi [5]. Jenis yang beragam dan anatomi tubuh ikan Maskoki yang hampir serupa membuat pecinta, pengamat, dan peneliti ikan Maskoki kesulitan untuk membedakan jenis-jenis ikan Maskoki terutama menggunakan foto (citra) ikan Maskoki. Identifikasi citra ikan Maskoki melalui beberapa tahap yaitu segmentasi, ekstraksi ciri, dan klasifikasi. Tahap segmentasi memberikan pengaruh yang sangat signifikan terhadap proses ekstrasi ciri. Semakin tinggi tingkat akurasi dalam segmentasi maka semakin tinggi tingkat keberhasilan proses ekstraksi ciri dalam mengidentifikasi sebuah citra. Segmentasi merupakan proses pemisahan citra menjadi bagian-bagian utama yang mengandung informasi paling penting dalam sebuah gambar [6].

Algoritma segmentasi citra umumnya didasarkan pada satu dari dua nilai intensitas, diskontinuitas dan similaritas. Pendekatan pertama dengan pemecahan citra berdasarkan 
perubahan kasar dalam intensitas, seperti tepi dalam citra. Pendekatan kedua didasarkan pada pemecahan citra menjadi region-region tertentu. Pembagian region berdasarkan sejumlah kriteria yang telah didefinisikan seperti thresholding, region growing dan region splitting [7]. Penelitian ini menggunakan pendekatan region dengan algoritma Expectation Maximization. Expectation Maximization (EM) merupakan sebuah algoritma yang menggunakan Maximum Likelihood Estimation (MLE) untuk menduga parameter suatu fungsi yang memiliki data tidak lengkap. Algoritma EM terbagi menjadi dua tahap yaitu Expectation (E-step) dan Maximization (M-step). E-step digunakan untuk mencari nilai ekspektasi untuk fungsi likelihood berdasarkan variabel yang diamati. Maximization (M-step) bertujuan untuk mencari MLE dari masing-masing parameter dengan memaksimumkan nilai ekspektasi dari loglikelihood yang dihasilkan oleh E-step [8].

Algoritma EM sudah digunakan untuk proses segmentasi gambar Ultrasound (US) Kista pada Liver [9]. Hasil segmentasi menggunakan EM berhasil mendeteksi kista pada liver daripada segmentasi menggunakan $K$-means clustering. Azhar et al. [10] menerapkan algoritma Expectation Maximization yang dikombinasikan dengan Hidden Markov Random Field (HMRF) pada segmentasi citra ikan tuna. Penelitian ini menggunakan tiga tahapan. Tahap pertama ialah konversi ruang warna HSI. Tahap kedua ialah segmentasi menggunakan cluster DBSCAN. Tahap terakhir adalah perbaikan tepi objek hasil segmentasi menggunakan HMRF-EM. Hasil uji coba menunjukkan bahwa ikan tuna berhasil terpisah dari background dengan tepi citra yang akurat.

Fokus penelitian ini ada pada proses segmentasi citra ikan Maskoki menggunakan algoritma EM. Proses segmentasi citra ikan maskoki merupakan salah satu rangkaian proses identifikasi spesies ikan Maskoki menggunakan citra digital. Hasil dari penelitian ini berupa citra ikan Maskoki dengan background berwarna grayscale. Citra ini akan mempermudah proses identifikasi ikan Maskoki secara keseluruhan. Spesies Ikan Maskoki yang akan digunakan adalah Fantail, Ranchu dan Oranda. Penelitian ini bertujuan untuk memisahkan antara objek ikan Maskoki dengan background pada citra digital. Pemisahan tersebut dilakukan untuk meningkatkan nilai akurasi pada proses identifikasi citra ikan Maskoki.

\section{Metode Penelitian}

Penelitian ini dibagi menjadi 3 tahapan yaitu akusisi citra, preprocessing citra, dan segmentasi citra. Diagram alir dalam penelitian ini dapat dilihat pada Gambar 1. Data dalam penelitian ini berupa citra ikan Maskoki yang diperoleh dari pengambilan data secara manual di beberapa tempat penjualan ikan Maskoki.

\section{A. Akuisisi Citra}

Penelitian ini menggunakan citra RGB dari tiga spesies ikan Maskoki yaitu Fantail, Oranda, Ranchu. Total citra yang digunakan berjumlah 216 dalam format penyimpanan jpg dan berukuran 1920 x 1080 piksel.

\section{B. Preprocessing Citra}

Citra hasil akuisisi menjadi input pada preprocessing. Tahap preprocessing diawali dengan me-resize ukuran citra menjadi lebih kecil dari aslinya. Selanjutnya, citra RGB diubah menjadi citra HSI. Langkah terakhir adalah merubah citra HSI menjadi citra grayscale.

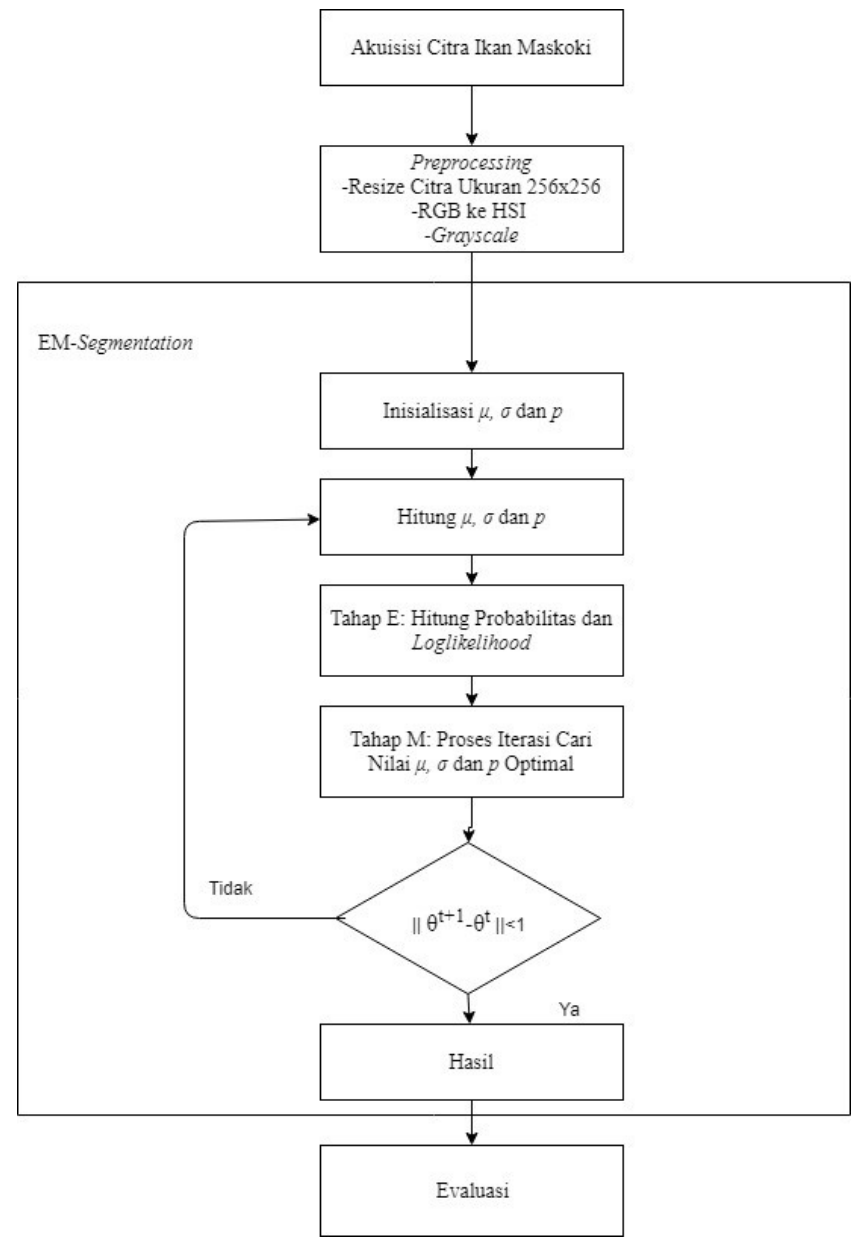

Gambar 1. Diagram alir segmentasi ikan Maskoki menggunakan algoritma EM

\section{Segmentasi}

Teknik segmentasi yang digunakan dalam penelitian ini adalah teknik segmentasi berbasis cluster. Citra ikan Maskoki dibagi menjadi 2 cluster. Cluster yang digunakan yaitu cluster pertama adalah objek dan cluster kedua adalah background. Metode yang digunakan dalam segmentasi adalah metode Expectation Maximization.

\section{Expectation Maximization (EM)}

Algoritma EM merupakan algoritma iteratif yang menghasilkan nilai Maximum Likelihood (ML) serta 
parameter-parameter baru, yaitu bobot mixture, mean, dan kovarian atau varian [11]. EM terdiri dari dua tahap yaitu $E$ step dan M-step. E-step digunakan untuk menghitung expected values (nilai dugaan) dari parameter berupa mean, varian serta probabilitas. $M$-step digunakan untuk menghitung kembali parameter yang sama dengan memaksimalkan nilai mean (rata-rata), varian serta probabilitas yang baru. Perbedaan yang digunakan untuk estimasi ulang parameter dilakukan secara berulang-ulang hingga mencapai lokal maksimum [8]. Tahapan penghitungan algoritma EM sebagai berikut:

1) Histogram Citra : Histogram citra adalah grafik yang menggambarkan frekuensi kemunculan nisbi (relative) dari intensitas pada citra tersebut [6]. Histogram digunakan sebagai alat bantu yang dapat menunjukkan kecerahan dan kontras dari citra ikan Maskoki. Perhitungan dari histogram akan digunakan untuk tahap segmentasi Expectation dan Maximization.

2) Inisialisasi Parameter: Parameter yang digunakan dalam proses inisialisasi adalah rata-rata $(\mu)$, varian $(\sigma)$, dan probabilitas (p).

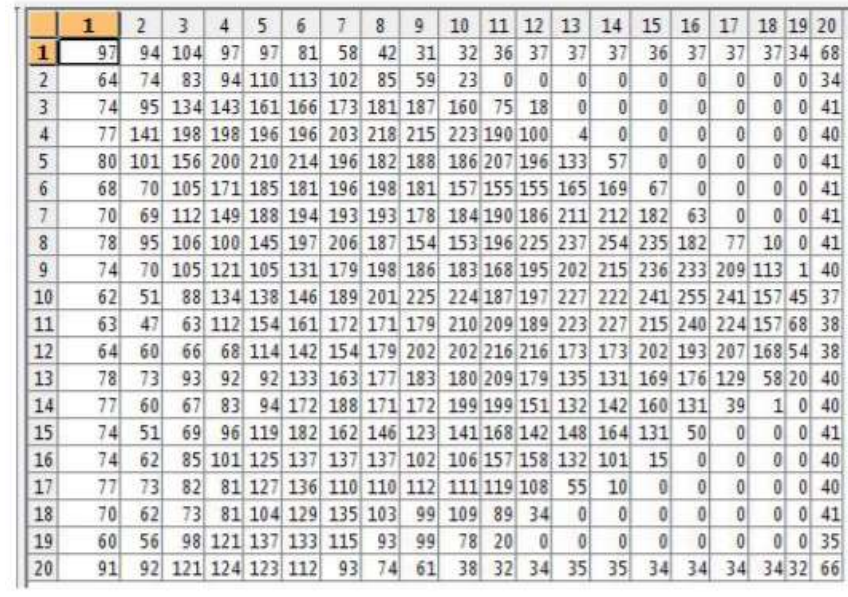

Gambar 2. Contoh nilai matriks citra [12]

Dari Gambar 2, nilai maksimum dan minimum dapat ditentukan berdasarkan kolom matriks. Gambar 3 merupakan nilai minimum berdasarkan kolom dan Gambar 4 merupakan nilai minimum berdasarkan baris.

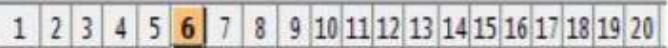

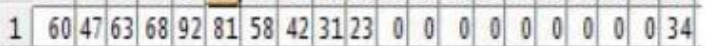

Gambar 3. Nilai minimum matriks citra [12]

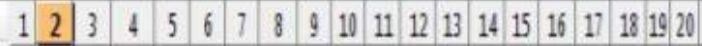 1 g7 $14119820021021420621822522421622523722542412552411686868 \mid$}

Gambar 4. Nilai maksimum matriks citra [12]

Jumlah klastes yang diinginkan adalah 3. Selanjutnya menghitung inisialisasi parameter rata-rata, varian dan probabilitas.
Parameter rata-rata menunjukkan ukuran dispersi dari suatu citra. Parameter rata-rata digunakan untuk mendapatkan nilai rata-rata setiap cluster dengan nilai maksimal piksel citra. Nilai rata-rata dihitung menggunakan rumus (1). c merupakan nilai cluster, ma merupakan nilai maksimal piksel yang dihitung menggunakan rumus (2), k merupakan jumlah cluster [13].

$\mu=\frac{c x m a}{k+1}$

ma $=$ max piksel - min piksel +1

Contoh perhitungan parameter rata-rata menggunakan nilai matriks citra pada Gambar 2. Nilai maksimum (ma) yang digunakan dalam contoh perhitungan adalah kolom ke 5 pada Gambar 4. Hasil perhitungan ditampilkan dalam Gambar 5.

\begin{tabular}{|c|c|c|c|}
\hline & 1 & 2 & 3 \\
\hline 1 & 52.5000 & 105 & 157,5000 \\
\hline
\end{tabular}

Gambar 5. Nilai rata-rata dengan nilai maksimum [12]

Parameter varian menunjukkan variasi elemen dari citra ikan Maskoki. Nilai varian dihitung menggunakan rumus (3). $\mathrm{m}, \mathrm{n}$ merupakan matriks baris dan kolom [13].

$V=(m, n) \times m a$.

Contoh perhitungan parameter varian menggunakan nilai matriks citra pada Gambar 2. Nilai maksimum (ma) yang digunakan dalam contoh perhitungan adalah kolom ke 5 pada Gambar 4. Hasil perhitungan ditampilkan dalam Gambar 6.

\begin{tabular}{|c|c|c|c|}
\hline & 1 & 2 & 3 \\
\hline 1 & 210 & 210 & 210 \\
\hline
\end{tabular}

Gambar 6. Nilai varian dengan nilai maksimum [12]

Parameter probabilitas digunakan untuk mendapat nilai peluang kemunculan intensitas pada citra. Nilai probabilitas dihitung menggunakan rumus (4) [13].

$p=(m, n) \times(1 / k) .$.

Contoh perhitungan parameter varian menggunakan nilai matriks citra pada Gambar 2. Hasil perhitungan ditampilkan dalam Gambar 7.

\begin{tabular}{|l|l|l|l|}
\hline & 1 & 2 & 3 \\
\hline 1 & 0.3333 & 0.3333 & 0.3333 \\
\hline
\end{tabular}

Gambar 7. Nilai probabilitas dengan nilai maksimum [12]

3) Tahap Expectation: Tahap Expectation (E-step) yang pertama adalah menghitung probabilitas dari distribusi parameter rata-rata, varian, dan probabilitas pada inisialisasi parameter. Nilai E-Step dihitung menggunakan rumus (5) dengan nilai $\mathrm{x}$ adalah nilai keabuan citra. Loglikehood adalah parameter yang memberikan kemungkinan yang paling besar 
untuk mendapatkan citra yang terobservasi. Nilai loglikehood dihitung menggunakan rumus (6) [13].

$E-$ Step $=\frac{p}{\sqrt{2 x \pi x v}} x \exp -\frac{1(x-\mu)}{2 v}$

loglikehood $=\sum$ Histogram $x \log \left(\sum_{i=1}^{k}\right.$ distribusi $\left._{i}\right)$

4) Tahap Maximization : Tahap Maximization (M-step) yang pertama adalah menghitung kembali rata-rata, varian dan probabilitas pada cluster kedua untuk mendapatkan nilai yang lebih optimal [13].

Kedua tahap tersebut dilakukan berulang-ulang sampai hipotesa dari converge (nilai yang terpusat) mencapai nilai yang statis. Setiap cluster dalam algoritma EM memiliki distribution probability (kemungkinan penyebaran) yang sama dan untuk setiap kejadian data digunakan parameter nilai estimate (perkiraan) pada setiap distribution (penyebaran) [13].

\section{E. Evaluasi}

Proses segmentasi dengan metode Expectation Maximization menghasilkan output berupa gambar ikan yang terpisah antara objek ikan dan background. Evaluasi dilakukan dengan membandingkan jumlah nilai piksel ikan Maskoki yang disegmentasi secara manual dengan jumlah nilai piksel ikan Maskoki yang disegmentasi menggunakan metode Expectation Maximization. Jumlah piksel ikan Maskoki yang lebih besar akan dijadikan sebagai pembanding.

\section{Hasil Dan Pembahasan}

Hasil dari penelitian ini berupa gambar ikan yang terpisah antara objek ikan Maskoki dan background.

\section{A. Data Penelitian}

Data yang digunakan dalam penelitian ini adalah citra ikan Maskoki spesies Fantail, Oranda, Ranchu. Ketiga spesies ini memiliki morfologi tubuh dan warna yang hampir serupa.

1) Ikan Maskoki Fantail : spesies Fantail memiliki bentuk tubuh mirip telur, sirip punggung tinggi, sirip ekor panjang empat kali lipat, dan tidak ada bonggol bahu. Sirip dubur memiliki ciri berjari tulang keras dan bergerigi serta seluruh bagian siripnya berbentuk rumbai-rumbai atau panjang [14]. Ciri-ciri tersebut merupakan bentuk morfologi yang hanya dimiliki oleh spesies Fantail. Ciri tersebut menjadi faktor pembeda spesies ini dengan spesies lainnya. Citra ikan Maskoki spesies Fantail dapat dilihat pada Gambar 8.

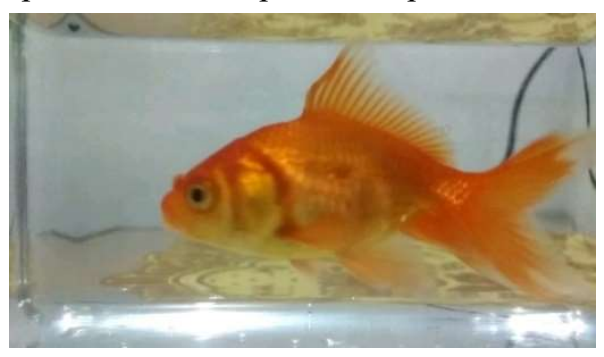

Gambar 8. Ikan Maskoki spesies Fantail

2) Ikan Maskoki Oranda: spesies Oranda memiliki kepala berjambul, kotak dan lebar, sirip punggungnya sama seperti Fantail. Oranda memiliki sirip ekor ganda namun lebih panjang dibandingkan dengan spesies Fantail [5]. Spesies ini memiliki ciri morfologi ekor yang hampir serupa dengan Fantail namun memiliki bentuk kepala yang berbeda. Oleh sebab itu, ciri khusus yang menjadi faktor pembeda spesies Oranda dengan spesies lain adalah bentuk kepala. Citra ikan Maskoki spesies Oranda dapat dilihat pada Gambar 9.

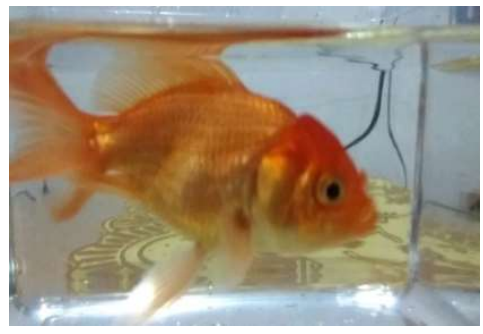

Gambar 9. Ikan Maskoki spesies Oranda

Ikan Maskoki Ranchu : spesies Ranchu memiliki bentuk kepala menyerupai segitiga tanpa jambul. Ikan Maskoki spesies ini tidak memiliki sirip punggung dan permukaan punggungnya yang sedikit lengkung atau bungkuk seperti busur panah. Sirip ekor Ranchu tergolong ekor ganda seperti spesies Oranda namun ukurannya lebih pendek daripada spesies Oranda [5]. Faktor pembeda utama spesies Ranchu dengan spesies lain terletak pada tidak adanya sirip punggung pada spesies ini. Citra ikan Maskoki spesies Ranchu dapat dilihat pada Gambar 10.

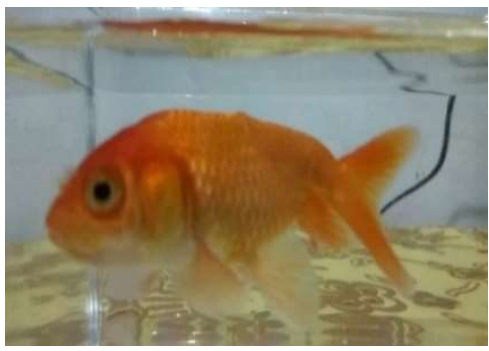

Gambar 10. Ikan Maskoki spesies Ranchu

Selain bentuk tubuhnya, ketiga spesies ini memiliki warna yang sama yaitu kuning keemasan. Perbedaan bentuk dari masing-masing spesies dapat dilihat pada Gambar 11.

\section{B. Preprocessing Citra}

Citra hasil akuisisi menjadi input pada preprocessing. Preprocessing diawali dengan me-resize ukuran citra menjadi 256x256 piksel. Selanjutnya, citra RGB diubah menjadi citra HSI untuk mendapatkan Hue dan Saturation. Nilai HS digunakan untuk memudahkan proses segmentasi citra ikan Maskoki dan background pada warna yang hampir mirip (serupa). Langkah terakhir dalam preprocessing ini adalah merubah nilai HS menjadi nilai grayscale. Hasil tahap preprocessing dapat dilihat pada Tabel I. 

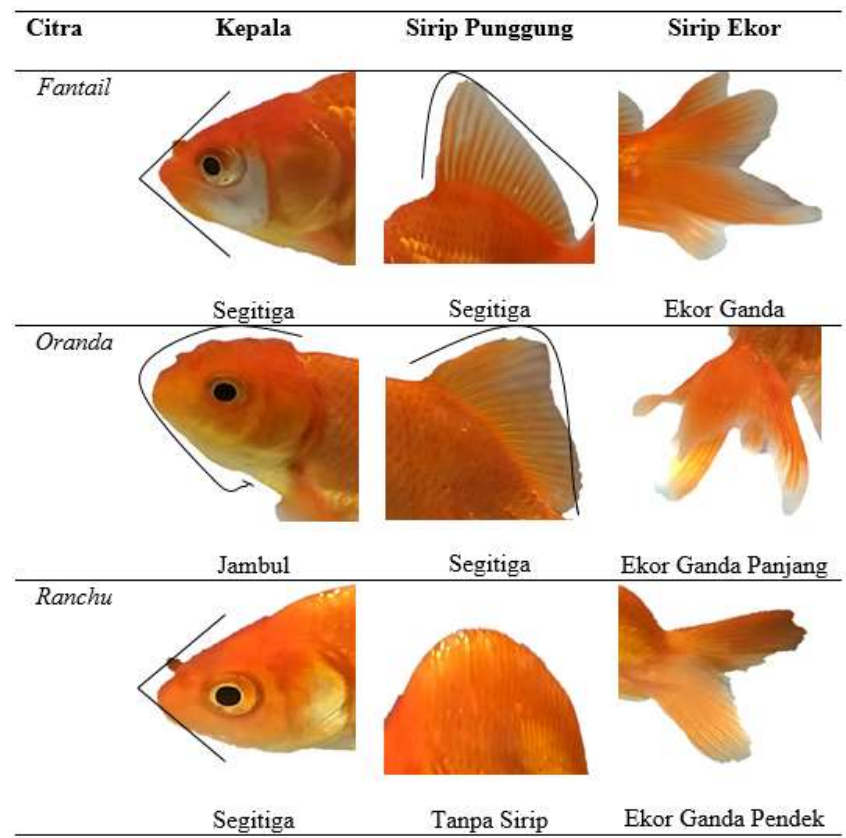

Gambar 11. Warna dan perbedaan morfologi tubuh ikan Maskoki

TABEL I

Contoh Hasil Pre-Processing Citra IKAN MASKoKI

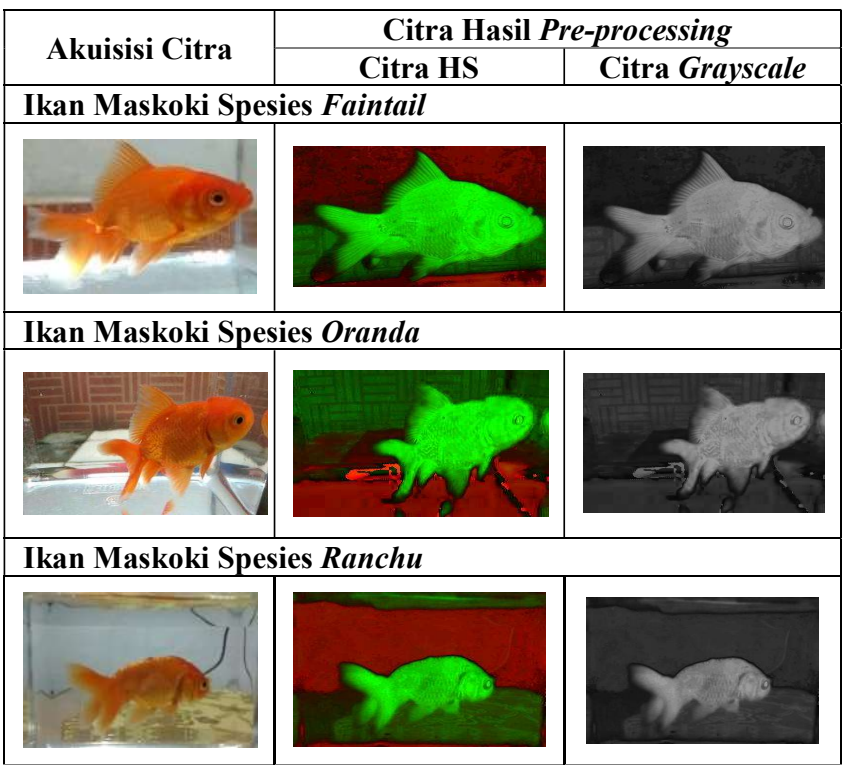

\section{Histogram Citra}

Citra ikan Maskoki memiliki matriks nilai citra berukuran 256 x 256. Potongan matriks salah satu citra ikan Maskoki spesies Fantail dapat dilihat pada Gambar 12.

\begin{tabular}{|l|l|l|l|l|l|l|}
\hline 21 & 22 & 23 & 24 & 22 & 21 & 22 \\
\hline 20 & 21 & 21 & 20 & 20 & 19 & 21 \\
\hline 18 & 18 & 18 & 20 & 20 & 20 & 21 \\
\hline 17 & 16 & 16 & 22 & 22 & 22 & 22 \\
\hline 17 & 17 & 17 & 23 & 24 & 25 & 24 \\
\hline 19 & 20 & 20 & 21 & 23 & 25 & 25 \\
\hline 21 & 22 & 23 & 20 & 22 & 25 & 25 \\
\hline 21 & 21 & 25 & 21 & 22 & 24 & 25 \\
\hline 22 & 20 & 24 & 21 & 24 & 25 & 26 \\
\hline 23 & 21 & 21 & 22 & 23 & 25 & 26 \\
\hline
\end{tabular}

Gambar 12. Potongan matriks citra ikan Maskoki

Distribusi nilai intensitas piksel dari citra grayscale ikan Maskoki diketahui melalui histogram. Pembuatan histogram citra ikan Maskoki menggunakan nilai dari hi=ni/n. Nilai hi menyatakan peluang piksel dalam derajat keabuan i. Peluang suatu piksel memiliki derajat keabuan lebih kecil atau sama dengan derajat keabuan tertentu. Nilai ni jumlah piksel yang memiliki jumlah derajat keabuan i dan nilai $\mathrm{n}$ adalah jumlah seluruh piksel dalam citra [6]. Histogram digunakan untuk pendugaan awal nilai-nilai piksel yang menunjukan area objek atau background pada citra ikan Maskoki. Gambar 13 merupakan distribusi intensitas piksel salah satu citra ikan Maskoki. Histogram akan digunakan untuk mencari nilai loglikehood pada tahap Expectation.

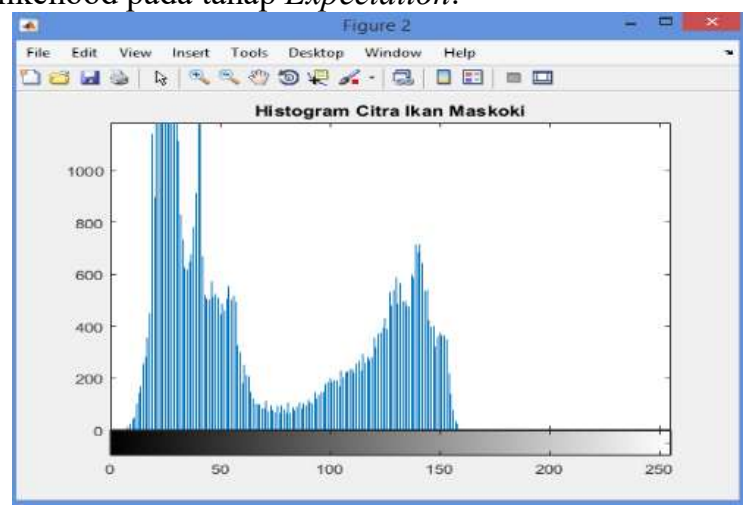

Gambar 13. Contoh Distribusi Sebaran Piksel Citra Ikan Maskoki

\section{Inisialisasi Parameter}

Parameter yang digunakan dalam algoritma EM adalah rata-rata dari ukuran dispersi suatu citra, varian elemen dari citra ikan Maskoki, dan probabilitas untuk mendapatkan nilai peluang kemunculan intensitas citra. Adapun contoh perhitungan untuk inisialisasi parameter citra pertama ikan Maskoki spesies Fantail adalah sebagai berikut:

1) Hitung nilai rata-rata : Hitung nilai rata-rata setiap cluster dengan nilai maksimal piksel citra ikan Maskoki menggunakan rumus (1). Nilai maksimal citra ikan Maskoki Fantail ke-1 adalah 179. Nilai minimal piksel citra ikan Maskoki Fantail ke-1 adalah 3. Nilai maksimal adalah 179$3+1=177$. Nilai rata-rata setiap cluster citra ikan Maskoki Fantail ke-1 dapat dilihat pada Gambar 14.

2) Varian : varian dihitung untuk menunjukkan variasi elemen dari citra ikan Maskoki. Varian dihitung dengan menggunakan matriks ones $(\mathrm{m}, \mathrm{n})$ dikalikan dengan maksimal nilai piksel. Matriks ones pada setiap elemennya bernilai 1 . 
Penelitian ini menggunakan matriks ones $1 \times 2$ dengan 2 sebagai cluster. Perhitungan nilai varian dilakukan menggunakan rumus (3). Ilustrasi perhitungan varian dapat dilihat pada Gambar 15.

$$
\begin{aligned}
\mu= & 1 \times \frac{177}{2+1}=59 \\
& =2 x \frac{177}{2+1}=118
\end{aligned}
$$

\begin{tabular}{|l|c|c|}
\hline \multirow{2}{*}{1} & $\mathrm{k} 1$ & $\mathrm{k} 2$ \\
\cline { 2 - 3 } & 59 & 118 \\
\hline
\end{tabular}

Gambar 14. Nilai rata-rata setiap cluster citra ikan Maskoki Fantail ke-1

$$
v=[11] \times 177=\left[\begin{array}{lll}
177 & 177
\end{array}\right]
$$

\begin{tabular}{|l|c|c|}
\hline \multirow{2}{*}{1} & $\mathrm{k} 1$ & $\mathrm{k} 2$ \\
\cline { 2 - 3 } & 177 & 177 \\
\hline
\end{tabular}

Gambar 15. Nilai varian citra ikan Maskoki Fantail ke-1

3) Probabilitas: Hitung probabilitas kemunculan intensitas citra dengan mengalikan antara matriks ones dengan $\frac{1}{\text { cluster }}$. Matriks ones merupakan matriks berordo mxn yang elemennya bernilai 1 . Ordo $\mathrm{m}$ (baris) diinisialisasi dengan nilai 1 dan ordo $\mathrm{n}$ (kolom) diinisialisasi dengan nilai 2 (sesuai cluster yang digunakan). Perhitungan nilai probabilitas dilakukan menggunakan rumus (4). Ilustrasi perhitungan probabilitas dapat dilihat pada Gambar 16.

$$
p=\left[\begin{array}{ll}
1 & 1
\end{array}\right] \times \frac{1}{2}=[0,5 \quad 0,5]
$$

\begin{tabular}{|l|l|l|}
\hline \multirow{2}{*}{1} & $\mathrm{k} 1$ & $\mathrm{k} 2$ \\
\cline { 2 - 3 } & 0,5 & 0,5 \\
\hline
\end{tabular}

Gambar 16. Nilai probabilitas citra ikan Maskoki Fantail ke-1

\section{E. Tahap Expectation (E-step)}

E-Step menghitung probabilitas dan loglikehood. Hitung distribusi probabilitas dengan nilai probabilitas, varian, dan rata-rata yang telah didapatkan pada tahap sebelumnya. Perhitungan E-Step menggunakan rumus (5). Ilustrasi perhitungan distribusi probabilitas adalah sebagai berikut:

$$
\begin{gathered}
\frac{0.5}{\sqrt{2 . \pi \cdot 177}} x \exp \left(-0,5 \times\left(\frac{(167-59)}{177}\right)\right) \\
=7.3529 \mathrm{e}-17
\end{gathered}
$$

Selanjutnya adalah menghitung nilai loglikelihood berdasarkan nilai distribusi probabilitas sebelumnya. Perhitungan loglikelihood menggunakan rumus (6). Ilustrasi perhitungan loglikelihood adalah sebagai berikut:

$$
\sum \text { Histogram } x \log \left(\sum_{1}^{2} \text { distribusi }\right)=-6.1692
$$

\section{F. Tahap Maximization (M-step)}

Perhitungan mean, varian dan probabilitas yang telah diperoleh pada E-Step digunakan kembali pada M-step. Perhitungan dalam $M$-step akan menghasilkan nilai maksimal dari setiap kemungkinan pada $E$-step.

\section{1) Menghitung Probabilitas Kedua}

Probabilitas kedua dihitung untuk mengoptimalkan proses iterasi nilai rata-rata, probabilitas dan varian. Dari E-step, diketahui nilai distribusi probabilitasnya adalah $(7.3529 \mathrm{e}-$ 17).

\section{2) Menghitung ulang probabilitas}

Probabilitas kedua menghasilkan matriks berukuran 7x2 . Total nilai yang didapatkan adalah 14 untuk setiap gambar ikan Maskoki. Seluruh nilai probabilitas tersebut kemudian dihitung jumlahnya dengan menggunakan fungsi Sum.

\section{3) Menghitung ulang rata-rata}

Total nilai rata-rata yang didapatkan adalah 2 nilai untuk setiap gambar ikan Maskoki. Kedua nilai rata-rata yang didapat kemudian dihitung jumlahnya dengan menggunakan fungsi Sum.

\section{4) Menghitung ulang varian}

Nilai varian tersebut kemudian dihitung jumlahnya dengan menggunakan fungsi Sum.

Hasil segmentasi menggunakan algoritma EM menghasilkan output berupa histogram dan gambar yang tersegmentasi. Sebaran nilai ditampilkan dalam bentuk histogram. Histogram digunakan untuk pembagian jumlah cluster. Pembagian jumlah cluster berdasarkan histogram penyebaran nilai dari masing-masing parameter. Histogram pembagian cluster dapat dilihat pada Gambar 17.

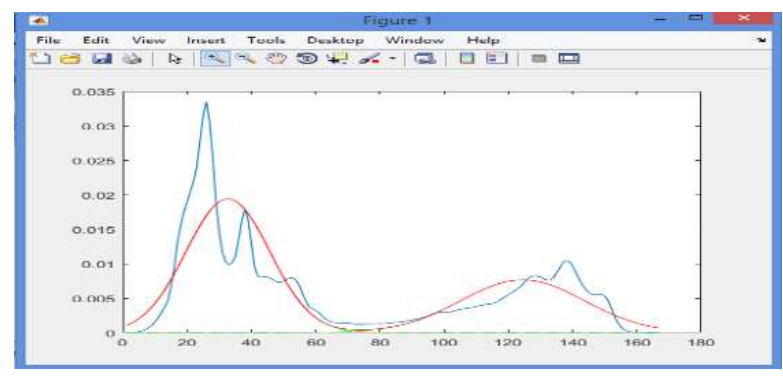

Gambar 17. Histogram Pembagian Cluster

Hasil metode segmentasi EM berupa matriks 256x256. Gambar 17 merupakan hasil pembagian cluster untuk citra pertama ikan Maskoki spesies Fantail. Nilai matriks hasil segmentasi pada citra tersebut adalah 179 dan 29. Warna 29 merupakan warna hitam pada objek yang terdeteksi sebagai ikan Maskoki sedangkan nilai warna 179 menunjukan warna 
abu-abu pada background. Ilustrasi sebaran matriks hasil segmentasi menggunakan algoritma EM dapat dilihat pada Gambar 18.

\begin{tabular}{|c|c|c|c|c|c|c|c|c|c|}
\hline 179 & 179 & 179 & 179 & 179 & 179 & 179 & 179 & 179 & 179 \\
\hline 179 & 179 & 179 & 179 & 179 & 179 & 179 & 179 & 179 & 179 \\
\hline 179 & 179 & 179 & 179 & 179 & 179 & 179 & 179 & 179 & 179 \\
\hline 179 & 179 & 179 & 179 & 179 & 179 & 179 & 179 & 179 & 179 \\
\hline 179 & 179 & 179 & 179 & 179 & 179 & 179 & 179 & 179 & 179 \\
\hline 29 & 179 & 179 & 179 & 179 & 179 & 179 & 179 & 179 & 179 \\
\hline 29 & 29 & 179 & 179 & 179 & 179 & 179 & 179 & 179 & 179 \\
\hline 29 & 29 & 29 & 29 & 179 & 179 & 179 & 179 & 179 & 179 \\
\hline 29 & 29 & 29 & 29 & 29 & 29 & 179 & 179 & 179 & 179 \\
\hline 29 & 29 & 29 & 29 & 29 & 29 & 29 & 29 & 29 & 179 \\
\hline 29 & 29 & 29 & 29 & 29 & 29 & 29 & 29 & 29 & 29 \\
\hline 29 & 29 & 29 & 29 & 29 & 29 & 29 & 29 & 29 & 29 \\
\hline 29 & 29 & 29 & 29 & 29 & 29 & 29 & 29 & 29 & 29 \\
\hline 29 & 29 & 29 & 29 & 29 & 29 & 29 & 29 & 29 & 29 \\
\hline 29 & 29 & 29 & 29 & 29 & 29 & 29 & 29 & 29 & 29 \\
\hline 29 & 29 & 29 & 29 & 29 & 29 & 29 & 29 & 29 & 29 \\
\hline 29 & 29 & 29 & 29 & 29 & 29 & 29 & 29 & 29 & 29 \\
\hline
\end{tabular}

Gambar 18. Potongan Matrik Hasil Segmentasi menggunakan Metode EM

\section{G. Hasil dan Evaluasi}

Hasil dari proses segmentasi adalah sebuah citra ikan Maskoki yang telah terpisah dari background dan objek lainnya. Hasil segmentasi dapat dilihat pada Tabel II.

TABEL II

HASIL SEGMENTASI IKAN MASKOKI MENGGUNAKAN EM

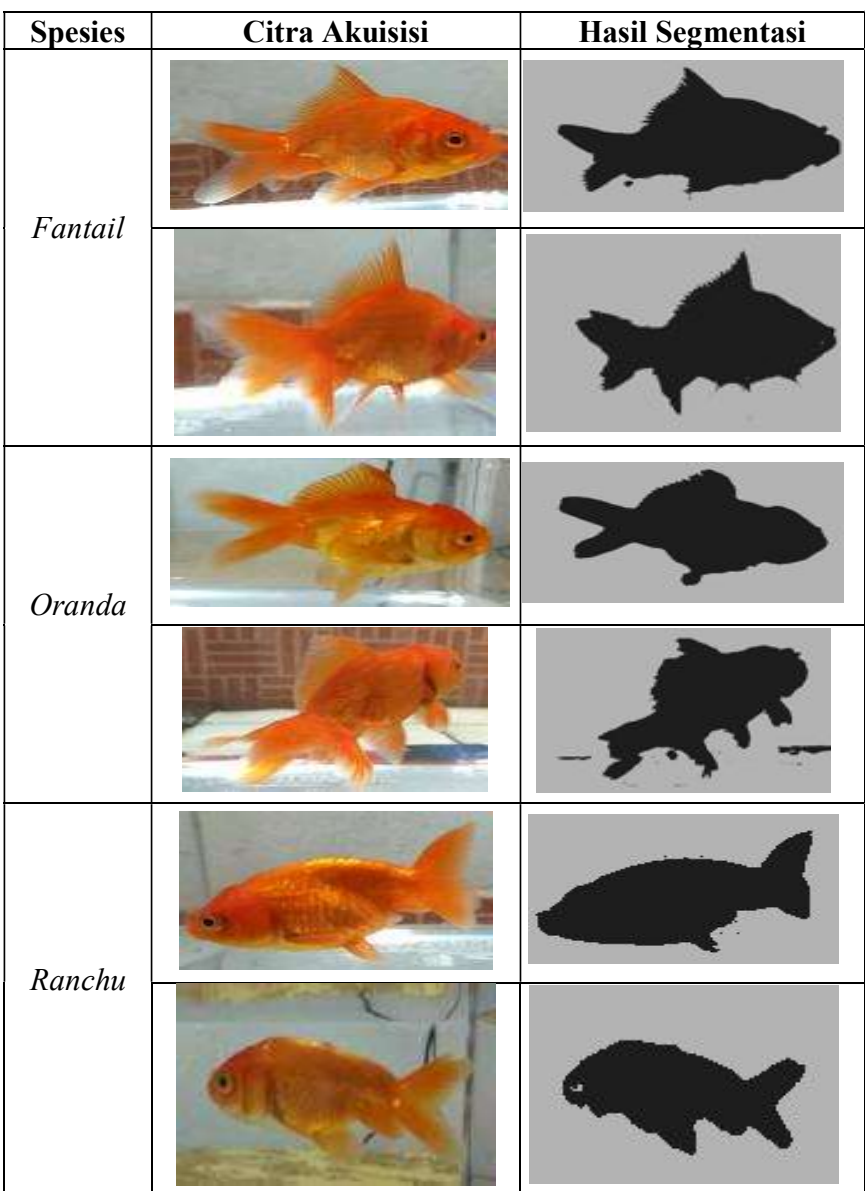

Evaluasi bertujuan untuk memperoleh tingkat akurasi dari hasil segmentasi yang telah didapat. Evaluasi diperoleh dari membagi jumlah piksel citra hasil segmentasi EM dengan jumlah piksel citra hasil segmentasi manual. Citra ikan Maskoki hasil segementasi manual diperoleh dari penelitian Pratidina [15]. Proses segmentasi manual dilakukan menggunakan bantuan software Corel Draw X4. Ukuran ikan maskoki diganti menjadi 256x256 piksel dan mengganti latar belakang citra menjadi putih. Citra RGB ikan mas koki yang telah berlatar belakang putih ditransformasi menjadi citra grayscale [15]. Selanjutnya, citra grayscale diubah menjadi warna hitam untuk objek ikan Maskoki dan warna abu-abu untuk background. Citra hasil segmentasi Pratidina digunakan sebagai alat ukur keberhasilan segmentasi menggunakan metode EM. Perbandingan hasil segmentasi manual dengan segmentasi EM dapat dilihat pada Tabel III.

TABEL III

Perbandingan Hasil Segmentasi EM dan Segmentasi ManUal

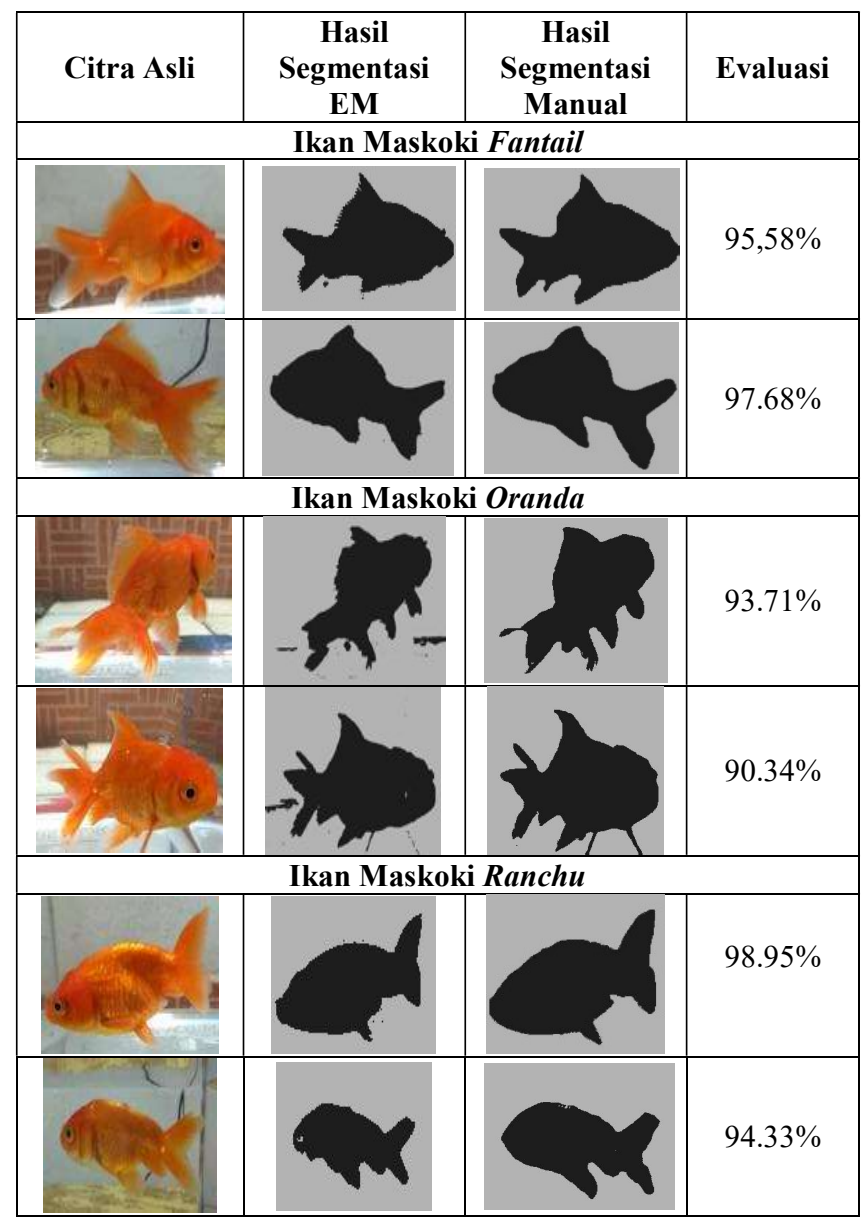

Hasil evaluasi segmentasi citra ikan Maskoki Fantail tertinggi mencapai 98,25\%. Hasil evaluasi terendah sebesar $88,03 \%$ sedangkan rata-rata hasil evaluasi adalah 93,28\%. Hasil evaluasi segmentasi citra ikan Maskoki Oranda tertinggi mencapai $96,93 \%$. Hasil evaluasi terendah sebesar $78,48 \%$ sedangkan rata-rata hasil evaluasi adalah $86,63 \%$. Hasil evaluasi segmentasi citra ikan Maskoki Ranchu tertinggi 98,95\%. Hasil evaluasi terendah adalah 79,94\% 
sedangkan rata-rata hasil evaluasi segmentasi citra ikan Maskoki Ranchu adalah 87,51\%. Rata-rata hasil segmentasi citra ikan Maskoki Fantail, Oranda, dan Ranchu adalah $89,14 \%$. Perbandingan hasil segmentasi citra Ikan Maskoki tertinggi ddan terrendah menggunakan metode EM dapat dilihat pada Tabel IV.

TABEL IV

HASIL SEGMENTASI CITRA IKAN MASKOKI TERTINGGI DAN TERRENDAH

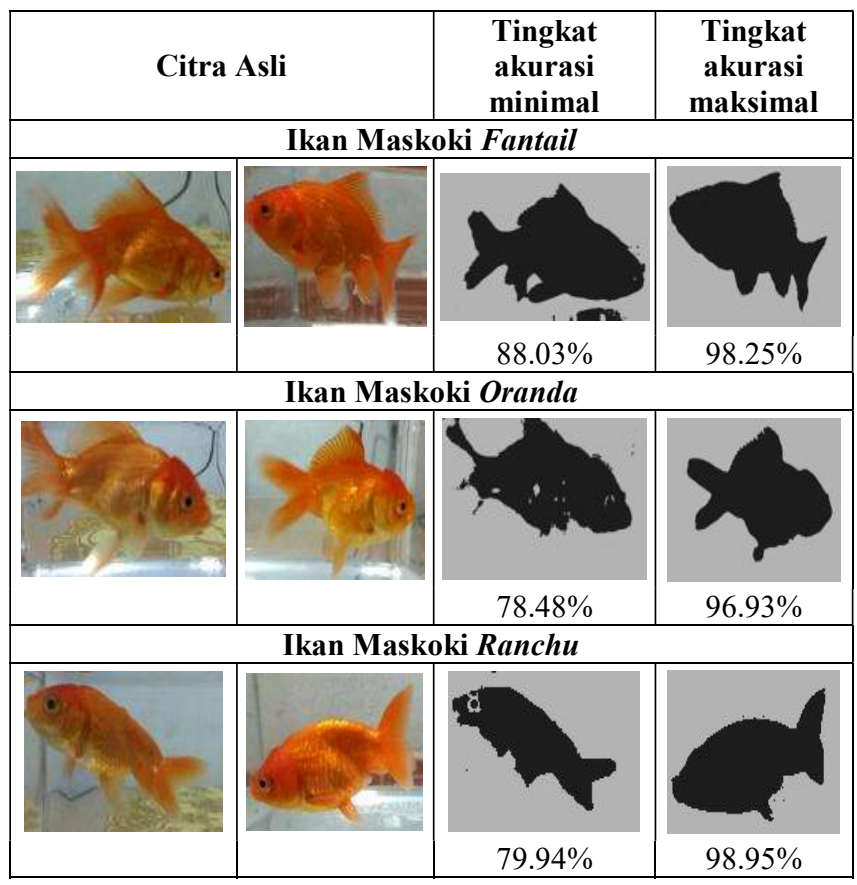

\section{H. Analisis Hasil Segmentasi}

Citra hasil akuisisi mempengaruhi hasil segmentasi. Semakin baik kualitas citra yang diakuisisi maka akan baik pula hasil segmentasinya. Tingkat rata-rata akurasi hasil segmentasi yang hanya mencapai $89,14 \%$ disebabkan oleh beberapa faktor. Faktor penyebab utama kegagalan adalah kesalah pengambilan gambar pada saat proses akusisi citra.

Kesalahan tersebut dapat dilihat pada Tabel V dan Tabel VI. Citra pada Tabel V menunjukkan adanya pembiasan cahaya berwarna putih pada citra. Bayangan dan pantulan cahaya warna putih disebabkan oleh kondisi pencahayaan yang terlalu terang. Cahanya tersebut menimbulkan bayangan pada permukaan akuarium sehingga bayangan ikut tersegmentasi. Citra pada Tabel VI merupakan contoh citra dengan tingkat akurasi yang rendah. Rendahnya nilai akurasi disebabkan intensitas warna foreground (ikan Maskoki) dengan background yang hampir serupa. Warna ikan Maskoki yang hampir mirip dengan background mengakibatkan sulitnya mendeteksi objek ikan Maskoki sehingga menimbulkan kesalahan segmentasi.

Proses akuisisi citra gambar mempengaruhi hasil kualitas segmentasi. Pengambilan objek citra harus memiliki fokus yang stabil dan tidak blur, sehingga menghasilkan tepian objek ikan Maskoki terlihat jelas dan tajam. Segmentasi ikan Maskoki terbaik dapat dilihat pada Tabel VII.

TABEL V

ANALISIS HASIL SEGEMENTASI FAKTOR 1

\begin{tabular}{|c|c|c|c|}
\hline Spesies & $\begin{array}{c}\text { Citra Hasil } \\
\text { Akuisisi } \\
\end{array}$ & $\begin{array}{l}\text { Citra Hasil } \\
\text { Segmentasi }\end{array}$ & $\begin{array}{c}\text { Hasil } \\
\text { Evaluasi }\end{array}$ \\
\hline Faintail & & & $88.03 \%$ \\
\hline Oranda & & & $82.81 \%$ \\
\hline Ranchu & & & $82.05 \%$ \\
\hline
\end{tabular}

TABEL VI

ANALISIS HASIL SEGEMENTASI FAKTOR 2

\begin{tabular}{|l|c|c|c|}
\hline Spesies & $\begin{array}{c}\text { Citra Hasil } \\
\text { Akuisisi }\end{array}$ & $\begin{array}{c}\text { Citra Hasil } \\
\text { Segmentasi }\end{array}$ & $\begin{array}{c}\text { Hasil } \\
\text { Evaluasi }\end{array}$ \\
\hline Oranda & & & \\
& & & \\
Ranchu & & & \\
\end{tabular}

TABEL VII

ANALISIS Hasil SEGEMENTASI TERBAIK

\begin{tabular}{|c|c|c|c|}
\hline Spesies & $\begin{array}{c}\text { Citra Hasil } \\
\text { Akuisisi }\end{array}$ & $\begin{array}{l}\text { Citra Hasil } \\
\text { Segmentasi }\end{array}$ & $\begin{array}{c}\text { Hasil } \\
\text { Evaluasi }\end{array}$ \\
\hline Fantail & & & $98.25 \%$ \\
\hline Oranda & & & $96.93 \%$ \\
\hline
\end{tabular}




\begin{tabular}{|l|c|c|c|}
\hline Spesies & $\begin{array}{c}\text { Citra Hasil } \\
\text { Akuisisi }\end{array}$ & $\begin{array}{c}\text { Citra Hasil } \\
\text { Segmentasi }\end{array}$ & $\begin{array}{c}\text { Hasil } \\
\text { Evaluasi }\end{array}$ \\
\hline Ranchu & & & \\
& & & \\
\hline
\end{tabular}

\section{KESIMPULAN}

Segmentasi citra ikan Maskoki menggunakan metode Expectation Maximization (EM) mampu bekerja dengan tingkat akurasi rata-rata sebesar $89,14 \%$. Akurasi ini merupakan nilai rata-rata dari tingkat akurasi rata-rata masing-masing spesies ikan Maskoki. Tingkat akurasi ratarata spesies Fantail sebesar 93,28\%, spesies Oranda sebesar $86,63 \%$, dan spesies Ranchu sebesar 87,51\%. Tahap penelitian selanjutnya adalah menggabungkan citra hasil segmentasi EM ini dengan metode gabor filter untuk membuat sistem identifikasi citra ikan Maskoki.

\section{UCAPAN TERIMA KASIH}

Penelitian ini tidak akan terlaksana tanpa bantuan dari pihak-pihak terkait. Tim peneliti mengucapkan terima kasih yang sebesar-besarnya kepada:

- LPPM Universitas Lampung yang telah membiayai riset ini sampai selesai.

- Mahasiswa yang terlibat (Susiyani, AA. Gieniung P., dan Erizky Wala) dalam penelitian ini baik dalam proses pengambilan data maupun proses pembuatan aplikasi.

\section{Daftar Pustaka}

[1] Kementerian Kelautan dan Perikanan RI, "Peta Lalulintas Ikan Hias 2018,” 2018. [Online]. Available: https://kkp.go.id/kkp/bkipm/artikel/6157-peta-lalulintas-ikan-hias2018 .

[2] T. A. Atmaji and C. Supriyanto, "Klasifikasi Jenis Ikan Koi Menggunakan Gray Level Co- Occurrance Matrix dan Algoritma Naive Bayes," Universitas Dian Nuswantoro, 2014.

[3] Kementerian Kelautan dan Perikanan, Pasar Ikan Hias Indonesia. Indonesia, 2016.

[4] Badan Pusat Statistik Kabupaten Sleman, "Produksi dan Harga Ikan Hias Air Tawar menurut Jenisnya di Kabupaten Sleman, 2016," Badan Pusat Statistik, 2017. [Online]. Available: https://slemankab.bps.go.id/statictable/2017/11/15/260/produksidan-harga-ikan-hias-air-tawar-menurut-jenisnya-di-kabupatensleman-2016.

[5] Y. Bachtiar and T. Lentera, Budidaya Ikan Hias Air Tawar untuk Ekspor, I. Tanggerang: PT. Agromedia Pustaka, 2020

[6] R. Munir, Pengolahan Citra Digital dengan Pendekatan Algoritmik. Bandung: Informatika, 2004.

[7] Eko Prasetyo, Pengolahan Citra Digital dan Aplikasinya Menggunakan Matlab. Yogyakarta: Andi, 2011.

[8] R. V Hogg, J. W. Mckean, and A. T. Craig, Introduction to Mathematical Statistics Seventh Edition. 2013.

[9] A. Khanna, M. Sood, and S. Devi, "US Image Segmentation Based on Expectation Maximization and Gabor Filter," vol. 2, no. 3, 2012, doi: 10.7763/IJMO.2012.V2.117.

[10] R. Azhar, A. Z. Arifin, and W. N. Khotimah, "INTEGRASI DENSITY-BASED CLUSTERING DAN HMRF-EM PADA," vol. 6 , no. 1, pp. 1-9, 2016.

[11] L. Handayani, "Identifikasi Area Kanker Ovarium pada Citra CT Scan Abdomen Menggunakan Metode Expectation Maximization," 2012,pp. 212-218.

[12] I. I. Septa, "ALGORITMA EXPECTATION MAXIMIZATION SEGMENTATION SEGMENTATION MAMMOGRAPHY BREAST CANCER WITH EXPECTATION MAXIMIZATION SEGMENTATION ALGORITHM ( EM-SEGMENTATION ) FOR RECOGNITION BREAST CANCER AREA," UNIVERSITAS ISLAM NEGERI SULTAN SYARIF KASIM RIAU, 2013.

[13] N. Mustapha, M. Jalali, and M. Jalali, "Expectation maximization clustering algorithm for user modeling in web usage mining system," 2009.

[14] Iskandar and M. Sitanggang, Memilih dan Merawat Maskoki Impor Berkualitas. Jakarta: Agromedia Pustaka, 2003.

[15] A.A. Gieniung Pratidina, "IDENTIFIKASI IKAN MASKOKI MENGGUNAKAN EKSTRAKSI FITUR GABOR FILTER DAN KLASIFIKASI PROBABILITY NEURAL NETWORK (PNN)," Universitas Lampung, 2018. 